\title{
Hemşirelerin Tıbbi Hata Eğilimlerine Yönelik Bir Çalışma
}

\section{A Study on Trends to Medical Error for Nurses}

\section{Özet}

\section{Işıl IŞIK}

\section{ANDSOY $^{1}$}

\section{Gülcan KAR}

\section{Özlem ÖZTÜRK ${ }^{1}$}

${ }^{1}$ Karabük

Üniversitesi Sağllk

Yüksekokulu

Hemşirelik Bölümü

Yazıșma Adresi

Correspondence

Iş11 IŞIK ANDSOY

Karabük Üniversitesi

Sağlık Yüksekokulu

Hemşirelik Bölümü,

Karabük Üniversitesi

Demir Çelik Kampüsü

100. Y1 / KARABÜK

Tel: 03704330202

GSM: 05326417803

isilandsoy@gmail.com

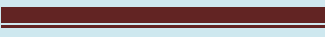

Gelis Tarihi /Recevied 16.06.2014

Kabul Tarihi/Accepted 24.06.204

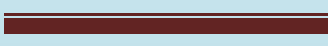

HSP 2014;1(1 ):17-27
Amaç: Araştırma hemşirelerin tıbbi hatalara eğilimlerinin belirlenmesi amacı ile yapıldı.

Yöntem: Tanımlayıcı ve kesitsel olan çalışma Nisan-Haziran 2013 tarihleri arasında Karabük'te yer alan özel bir hastanede çalışan ve aydınlatılmış onam alınan toplam 125 hemşire ile yapıldı. Veriler, "Hemşirelikte Tıbbi Hataya Eğilim Ölçeği” kullanılarak toplandı. Çalışmada ortalama, yüzdelik, Kruskal Wallis ve Mann-Whitney U testi kullanıldı. Bulgular: Hemşirelerin Tıbbi Hataya Eğilim Ölçeğinden alınan toplam puan ortalamasının $4.80 \pm 0.21$ ve tıbbi hata yapma eğilimlerinin düşük olduğu belirlendi. Hemşirelerin alt boyutlara ilişkin aldıkları en yüksek puan ortalamalarının enfeksiyonun önlenmesi ( $\bar{x}$ $=4.83 \pm 0.24)$ ve iletişim $(\bar{x}=4.83 \pm 0.31)$, en düşük puan ortalamalarının ise hasta izlemi ve malzeme cihaz güvenliği $(\bar{x}=4.72 \pm 0.31)$ olduğu saptandı. Hemşirelerin çalıştıkları klinik ile "ilaç ve transfüzyon uygulamaları" ( $\mathrm{p}=0.017)$, eğitim alma durumu ile "enfeksiyonların önlenmesi" ve "hasta izlemi ve malzeme cihaz güvenliği" alt boyut puan ortalamaları arasında istatistiksel olarak anlamlı bir fark bulundu $(\mathrm{p}=0.043, \mathrm{p}=0.031)$. Sonuç: Hemşirelerin tıbbi hata yapma eğilimlerinin düşük olduğu görülmekle birlikte tıbbi hataların azaltılmasına yönelik eğitimlerin yapılması, hasta güvenliği bilincinin oluşturulmasına katkı sağlayabilir.

Anahtar Kelimeler: Eğilim, hasta güvenliği, hemşire, tıbbi hata.

\begin{abstract}
Objective: This study aims to determine the level of proneness to medical error among nurses. Method: The descriptive and cross-sectional study was performed with the voluntary participation of 125 nurses working in a Private Hospital in Karabük in AprilJune 2013. The data were collected by using "Medical Error Trend Scale in Nursing". In the study, percentages, averages, Kruskal Wallis and Mann Whitney U tests were used in statistical analysis. Results: The proneness to medical error among nurses was low. The mean score for Medical error Trend Scale was found as $4.80 \pm 0.21$ of all subscales, the highest score came from prevention of infection $(\bar{x}=4.83 \pm 0.24)$, and communication $(\bar{x}$ $=4.72 \pm 0.31)$, while the lowest scores came from the patient monitoring and the safety of medical equipment $(\bar{x} 4.63 \pm 0.59)$. There was a significant relationship between the subscales of "drug and transfusion practices" and working clinics $(\mathrm{p}=0.017)$, and also there was a significant relationship between training of education and the subscales of "prevention of infection" and "patient follow-up and material device security" $(p=0.043, p=0.031)$. Conclusion: Despite the obtained low scores, making training for the reduce of medical errors can contribute to the creation of awareness for patient safety.
\end{abstract}

Keywords: Trend, patient safety, nurse, medical error. 


\section{Giriş}

Tıbbi hata, hastaya sunulan sağlık hizmeti sırasında kasıtsız bir aksamanın neden olduğu; beklenmeyen ölüm, ciddi fiziksel veya psikolojik hasar veya hasar riskini içeren ters ve beklenmeyen olaylardır. ${ }^{1}$ Literatürde tüm dünya ülkelerinde tıbbi hatalara sıklıkla rastlanıldığı belirtilmektedir. ${ }^{2-4}$ Ülkemizde ise, tıbbi hatalar ve hasta güvenliği ile ilgili retrospektif olarak hasta kayıtlarından incelenerek yapılmış ulusal sonuçları yansıtan çalışmalar bulunmamakla birlikte, sağlık ekibi üyelerinin hasta güvenliği ile ilgili bilgilerini değerlendiren, hatalarla ilgili görüş ve deneyimlerini yansıtan çalışmalara rastlanmaktadır. ${ }^{5-9}$

Sağlık hizmetleri sunumunda tıbbi hatalar genel olarak, uygulama ve planlama hataları üzerine yoğunlaşmaktadır. Uygulama hataları; planlanan tedavinin planlandiğı şekilde tamamlanmaması sonucu amacına ulaşmamasıdır. Planlama hataları ise; amaca ulaşmada yanlış planlama veya yanlış bir plan kullanılması şeklinde görülebilir. ${ }^{1,2}$ Yanlış tıbbi uygulama veya tedavi planını tamamlayamama gibi durumlarda; hastanın ölümü, sakat kalması, uzun süreli hastanede yatması gibi sonuçlar ters etkiler olarak değerlendirilmektedir. ${ }^{2,10}$ Herhangi bir tıbbi hata oluşması durumunda başta hasta olmak üzere, hasta yakınları, sağlık profesyonelleri ve sağlık sistemleri olumsuz yönde etkilenir. Bu bağlamda, tıbbi hatalar tedavinin uzaması, yeni sakatlıkların veya komplikasyonların tedavisi, ilaç harcamalarının artması sonucunda ilave maliyetlere ve manevi hasara neden olmaktadır. ${ }^{11}$ Ayrıca tıbbi hatalar sağlık profesyonellerinin moral ve motivasyon kaybını, hastalarda ise sağlık personeline güvensizliği ve toplumda sağlık sisteminden memnuniyetsizliği beraberinde getirmektedir. ${ }^{1}$

Tıbbi hataların nedenlerinin kişilerden çok organizasyon yapısı, teknik altyapı ve insan gücü yetersizliği gibi sistemle ilgili sorunlar olduğu belirlenmiştir. ${ }^{2,7,12,13}$ Hastanelerde insan hataları; iletişimsizlik, etkin eğitimin olmaması, dikkatsizlik, yorulma, tükenme, stres, ihmal, gürültülü çalışma koşulları ile kişisel ve çevresel faktörler gibi birden fazla nedene bağlı olabilmektedir. Hemşirelik hizmetleri bakımında ise tıbbi hataların dikkatsizlik, tedbirsizlik, meslekte acemilik, yetersizlik, özen eksikliği ile emir ve yönetmeliklere uymama gibi nedenlerden kaynaklandı̆̆ belirtilmektedir. ${ }^{1,14}$ Hemşirelik mesleği ile ilgili yapılan tıbbi hatalar, bakım standartlarını planlama, uygulama, değerlendirme, kayıt tutma; iletişim ve hasta güvenliği ile ilgili girişimlerin yetersizliğidir. ${ }^{1,14,15}$

Hemşirelerin, tıbbi hataların önlenmesinde ayrı bir önemi bulunmaktadır. Hastanın güvenli bir ortamda ihmal ve her türlü zarar verici uygulamadan korunarak bakım görmesi temel hasta haklarından biridir. Hemşireler hizmet sunduğu her ortamda, hastaya uygulanacak işlem ve tedavilerin istenmeyen sonuçlarını önleme ve tehlikelerden korumada sorumludurlar. Hemşirelerin bu sorumluluklarını yerine getirebilmesi için hasta güvenliğini bozan çok boyutlu etmenlere karşı dikkatli olmalı, hastalarını kapsamlı şekilde değerlendirmeli ve bireysel bakım uygulamalarında 
hasta güvenliğini koruma ve geliştirmeye özen göstermelidir., ${ }^{1,6,8,16,17} \mathrm{Bu}$ bilgiler doğrultusunda çalışmada, hemşirelerin tıbbi hatalara eğilimlerinin belirlenmesi amaçlandı.

\section{Gereç ve Yöntem}

Tanımlayıcı ve kesitsel tipte olan çalışma, Nisan-Haziran 2013 tarihleri arasında Karabük'te yer alan 100 yataklı özel bir hastanede yapıldı. Çalışmanın yapıldığı hastanede Sağlık Bakanlığ1 direktifleri doğrultusunda 2012 yılından itibaren kalite çalışmaları devam etmekte, hasta güvenliğ ve tıbbi hatalara yönelik hizmet içi eğitimler yapılmaktadır. Hemşireler gece- gündüz vardiyası olmak üzere iki vardiya şeklinde çalışmaktadır. Çalışmanın evrenini hastanede çalışan toplam 140 hemşire oluşturdu. Çalışmada örneklem seçimine gidilmedi, araştırmanın yapıldı̆̆ı tarihte izinli, raporlu olan, araştırmaya katılmayı kabul etmeyen, veri toplama formunda hata tespit edilen 15 hemşire kapsam dışı bırakıldı. Araştırmaya katılmayı kabul eden ve aydınlatılmış onam alınan toplam 125 hemşire örneklem grubunu oluşturdu.

\section{Veri toplama araçları}

Veri toplamada Kişisel Bilgi Formu ve "Hemşirelikte Tıbbi Hataya Eğilim Ölçeği” kullanıldı.

Kişisel Bilgi Formu; araştırmacılar tarafından ilgili literatür doğrultusunda hazırlanan, hemşirelerin tanıtıcı özelliklerini (cinsiyet, yaş, eğitim durumu v.b.), mesleki özelliklerini (çalışma süresi, birimi ve görevi), tıbbi hatalarını, tıbbi hatalara yönelik aldığı eğitimi sorgulayan toplam 14 sorudan oluşmaktadır.

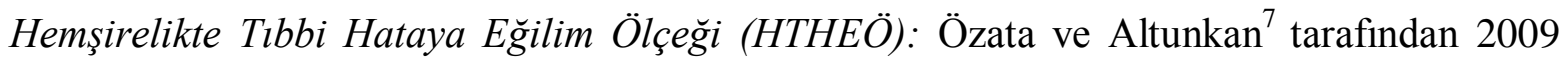
yılında geliştirilmiştir, geçerlik ve güvenirliği yapılmıştır. Ölçekte hemşirelerin hasta bakımında günlük rutin olarak yerine getirdikleri faaliyetleri içeren 49 madde ve 5 alt boyut yer almaktadır. Hemşirelerden, ölçekte yer alan her maddenin kendileri için uygun olanı işaretlemeleri istenmiştir. Ölçek likert tipi 5 kategoride değerlendirilir. 1: hiç, 2: çok nadir, 3: zaman zaman, 4: genellikle, 5: her zaman şeklinde değerlendirilmektedir. Ölçekten alınan en düşük puan 45, en yüksek puan 245 'tir. Toplam puanların artması hemşirelerin tıbbi hata yapmaya eğilimlerinin azaldığı şeklinde yorumlanmaktadır. Ölçeğin iç tutarlılık güvenirlik katsayısı Cronbach Alpha 0.95 olarak bulunmuştur. Çalışmamızda ölçeğin Cronbach Alpha değeri 0.93 olarak bulundu. Ölçeğin alt boyutlarının iç tutarlılık güvenirlik katsayıları ise "İlaç ve Transfüzyon Uygulamaları" alt boyutu için 0.82, "Enfeksiyonların Önlenmesi" alt boyutu için 0.85, "Hasta İlemi ve Malzeme- Cihaz Güvenliği " alt boyutu için 0.78, "Düşmelerin Önlenmesi” alt boyutu için 0.65, "İletişim” alt boyutu için 0.77 olarak bulunmuştur. Bu sonuçlar ölçeğin ve alt boyutların (düşmelerin önlenmesi dışında) yeterli güvenirlikte olduğunu (Cronbach Alpha >0.70) göstermektedir. 
Işıl IŞIK ANDSOY, Gülcan KAR, Özlem ÖZTÜRK

\section{Çalışmanın Etik Yönü}

Çalışmaya başlamadan önce ilgili kurumdan gerekli izinler alındı. Çalışmaya katılan hemşirelere, çalışmanın amacı, yöntemi ve yararları açıklanarak çalışmaya katılmaya istekli olup olmadıkları soruldu ve izinleri alındı. Araştırmalarda insan olgusunun kullanımında bireysel hakların, korunması gerektiğinden “İsteklilik, Gönüllük” ilkesi ışığında “Bilgilendirilmiş Onam” koşulu yerine getirildi.

\section{Verilerin Analizi}

Hemşirelikte Tıbbi Hataya Eğilim Ölçeği ve 5 alt boyutun madde puan ortalamaları, standart sapmaları, ölçeğin ve alt boyutların iç tutarlılık katsayıları (Cronbach Alpha) hesaplandı. Verilerin analizinde ortalama ve yüzdelik hesaplama, non-parametrik testlerden Kruskal Wallis ve MannWhitney U Testi kullanıldı.

\section{Bulgular}

Hemşirelerin yaş ortalaması ise 24.12 44.15 (18-37)'dir. \%78.4'ü kadın, \%57.6'sı sağlık meslek lisesi mezunu, \%43.2'si cerrahi birimlerde, \%56's1 ise servislerde görev yapmakta, \%47.2'si ise 1 yıldan az süredir çalışmaktadır.

Çalışma grubunun \% 78.4'ü mesleki çalışma süresinde herhangi bir tıbbi hatası olmadığını, \%39.2'si dikkatsiz çalışma stilini ve \%28'i eğitim yetersizliği ve iletişimsizliği, \%13.6'sı işini umursamamayı, \%9.6'sı motivasyon eksikliğini, \%4.8'i yoğun çalışmayı tıbbi hata nedeni olarak belirttiler. Hemşirelerin \%93.6’sının hasta güvenliğine yönelik eğitim aldıkları saptandı.

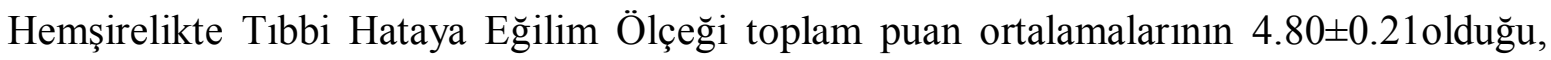
hemşirelerin alt boyutlara ilişkin aldıkları en yüksek puan ortalamalarının enfeksiyonun önlenmesi ( $\bar{x}=4.83 \pm 0.003$ ) ve iletişim ( $\bar{x}=4.83 \pm 0.003$ ), en düşük puan ortalamalarının ise hasta izlemi ve malzeme cihaz güvenliği ( $\bar{x}=4.72 \pm 0.012$ ) olduğu belirlendi (Tablo 1 ). 
Tablo 1. Hastanede çalışan hemşirelerin Hemşirelikte Tıbbi Hataya Eğilim Ölçeği alt grup puan ortalamaları

\begin{tabular}{|c|c|c|c|c|}
\hline HTHEÖ Alt Grupları & $\begin{array}{l}\text { Dağılım } \\
\text { aralığ } 1\end{array}$ & $\begin{array}{l}\text { Madde } \\
\text { say1s1 }\end{array}$ & $\begin{array}{l}\text { Puan } \\
\text { rtalamalar1 } \\
\bar{x} \pm \mathrm{SS} \\
\end{array}$ & $\begin{array}{l}\text { Madde puan } \\
\text { ortalamalar1* } \\
\bar{x} \pm \mathrm{SS} \\
\end{array}$ \\
\hline İlaç ve Transfüzyon Uygulamaları & $18-90$ & 18 & $86.44 \pm 4.23$ & $4.80 \pm 0.015$ \\
\hline Enfeksiyonların Önlenmesi & $12-60$ & 12 & $57.96 \pm 2.95$ & $4.83 \pm 0.003$ \\
\hline $\begin{array}{l}\text { Hasta İzlemi ve Malzeme Cihaz } \\
\text { Güvenliği }\end{array}$ & $9-45$ & 9 & $42.55 \pm 2.79$ & $4.72 \pm 0.012$ \\
\hline Düşmelerin Önlenmesi & $5-25$ & 5 & $24.08 \pm 1.44$ & $4.81 \pm 0.014$ \\
\hline İletişim & $5-25$ & 5 & $24.18 \pm 1.55$ & $4.83 \pm 0.003$ \\
\hline HTHEÖ Genel & $49-245$ & 49 & $235.33 \pm 10.40$ & $4.80 \pm 0.21$ \\
\hline
\end{tabular}

* Her maddeden alınabilecek en yüksek puan 5'tir

Ölçek alt boyutları puan ortalamaları ile cinsiyet, öğrenim durumu, görev süresi, meslekte çalışma süresi, mesleki yaşamında tıbbi hata yapma durumu ve tıbbi hataya neden olan faktörlere yönelik düşünceleri ile HTHEÖ ölçeği alt boyutları puan ortalamaları arasında istatistiksel olarak anlamlı bir fark bulunmadi ( $>>0.05)$ ( Tablo 2).

Hemşirelerin çalıştıkları klinik ile HTHEÖ ölçeği “ilaç ve transfüzyon uygulamaları” alt boyutu puan ortalaması arasında istatistiksel olarak anlamlı fark bulundu $(p=0.017, p<0.05)$, ayrica hemşirelerin daha önce hasta güvenliği hakkında eğitim alma durumu ile sırasıyla HTHEÖ ölçeği “enfeksiyonların önlenmesi” ve "hasta izlemi ve malzeme cihaz güvenliği” alt boyut puan ortaları arasında istatistiksel olarak anlamlı bir fark bulundu ( $\mathrm{p}=0.043, \mathrm{p}=0.031, \mathrm{p}<0.05)$ (Tablo 2). 
Tablo 2. Bazı Değişkenlere Göre Hemşirelikte Tıbbi Hataya Eğilim Ölçeği Puan Ortalamalarının Karşılaştırılması (N=125)

\begin{tabular}{|c|c|c|c|c|c|c|c|c|}
\hline & \multirow[t]{3}{*}{ Değişkenler } & \multirow[b]{3}{*}{$\mathbf{N}$} & \multirow[b]{3}{*}{$\%$} & $\begin{array}{c}\text { İlaç ve } \\
\text { Transfüzyon } \\
\text { Uygulamaları }\end{array}$ & $\begin{array}{l}\text { Enfeksiyonların } \\
\text { Önlenmesi }\end{array}$ & $\begin{array}{c}\text { Hasta İzlemi } \\
\text { ve Malzeme } \\
\text { Cihaz } \\
\text { Güvenliği }\end{array}$ & $\begin{array}{l}\text { Düşmelerin } \\
\text { Önlenmesi }\end{array}$ & İletişim \\
\hline & & & & $\bar{x} \pm \mathbf{S S}$ & $\bar{x} \pm \mathbf{S S}$ & $\bar{x} \pm \mathbf{S S}$ & $\bar{x} \pm \mathbf{S S}$ & $\bar{x} \pm \mathbf{S S}$ \\
\hline & & & & $4.80 \pm 0.23$ & $4.83 \pm 0.24$ & $4.72 \pm 0.31$ & $4.81 \pm 0.28$ & $4.83 \pm 0.31$ \\
\hline Cinsiyet & $\begin{array}{l}\text { Kadın } \\
\text { Erkek }\end{array}$ & $\begin{array}{l}98 \\
27\end{array}$ & $\begin{array}{l}78.4 \\
21.6\end{array}$ & $\begin{array}{l}\mathrm{z}=-1.14 \\
\mathrm{p}=0.254\end{array}$ & $\begin{array}{l}\mathrm{z}=-1.06 \\
\mathrm{p}=0.287\end{array}$ & $\begin{array}{l}\mathrm{z}=-0.55 \\
\mathrm{p}=0.577\end{array}$ & $\begin{array}{c}\mathrm{z}=0.12 \\
\mathrm{p}=0.898\end{array}$ & $\begin{array}{l}\mathrm{z}=-0.76 \\
\mathrm{p}=0.442\end{array}$ \\
\hline $\begin{array}{l}\text { Öğrenim } \\
\text { durumu }\end{array}$ & $\begin{array}{l}\text { SML } \\
\text { Önlisans } \\
\text { Lisans }\end{array}$ & $\begin{array}{l}72 \\
17 \\
36\end{array}$ & $\begin{array}{l}57.6 \\
13.6 \\
28.8\end{array}$ & $\begin{array}{l}x^{2}=3.15 \\
p=0.207\end{array}$ & $\begin{array}{l}x^{2}=5.56 \\
p=0.062\end{array}$ & $\begin{array}{l}x^{2}=4.91 \\
p=0.086\end{array}$ & $\begin{array}{l}x^{2}=0.98 \\
p=0.610\end{array}$ & $\begin{array}{l}\mathrm{X}^{2}=1.84 \\
\mathrm{P}=0.056\end{array}$ \\
\hline Görev süresi & $\begin{array}{l}0-1 \text { yildan az } \\
1-5 \text { yıl } \\
5 \text { yıl ve üzeri }\end{array}$ & $\begin{array}{l}59 \\
39 \\
27\end{array}$ & $\begin{array}{l}47.2 \\
31.2 \\
21.6\end{array}$ & $\begin{array}{l}\mathrm{X}^{2}=2.87 \\
\mathrm{P}=0.238\end{array}$ & $\begin{array}{c}\mathrm{X}^{2}=2.22 \\
\mathrm{P}=0.328\end{array}$ & $\begin{array}{l}\mathrm{X}^{2}=5.14 \\
\mathrm{P}=0.076\end{array}$ & $\begin{array}{l}\mathrm{X}^{2}=1.32 \\
\mathrm{P}=0.516\end{array}$ & $\begin{array}{l}\mathrm{x}^{2}=1.43 \\
\mathrm{P}=0.488\end{array}$ \\
\hline Çalıştığı Klinik & $\begin{array}{l}\text { Dahili Birimler } \\
\text { Cerrahi Birimler } \\
\text { Yoğun Bakım } \\
\text { Acil Servis }\end{array}$ & $\begin{array}{c}28 \\
54 \\
34 \\
9\end{array}$ & $\begin{array}{c}22.4 \\
43.2 \\
27.2 \\
7.2\end{array}$ & $\begin{array}{l}x^{2}=10.17 \\
\mathbf{p}=\mathbf{0 . 0 1 7}\end{array}$ & $\begin{array}{l}x^{2}=5.96 \\
p=0.113\end{array}$ & $\begin{array}{l}x^{2}=5.49 \\
p=0.139\end{array}$ & $\begin{array}{l}\mathrm{x}^{2}=3.43 \\
\mathrm{P}=0.330\end{array}$ & $\begin{array}{l}\mathrm{X}^{2}=3.92 \\
\mathrm{P}=0.270\end{array}$ \\
\hline $\begin{array}{l}\text { En az bir hata } \\
\text { yapma } \\
\text { durumu }\end{array}$ & $\begin{array}{l}\text { Evet } \\
\text { Hayır }\end{array}$ & $\begin{array}{l}27 \\
98\end{array}$ & $\begin{array}{l}21.6 \\
78.4\end{array}$ & $\begin{array}{l}\mathrm{z}=-1.59 \\
\mathrm{p}=0.111\end{array}$ & $\begin{array}{l}\mathrm{z}=-0.09 \\
\mathrm{p}=0.925\end{array}$ & $\begin{array}{l}\mathrm{z}=-0.35 \\
\mathrm{p}=0.723\end{array}$ & $\begin{array}{l}\mathrm{z}=-1.15 \\
\mathrm{p}=0.249\end{array}$ & $\begin{array}{l}\mathrm{z}=-0.08 \\
\mathrm{p}=0.936\end{array}$ \\
\hline $\begin{array}{l}\text { Tibbi hata } \\
\text { nedenleri }\end{array}$ & $\begin{array}{l}\text { Dikkatsiz çalışma stili } \\
\text { Eğitim yetersiz. ve iletişimsizlik } \\
\text { İşini umursamama } \\
\text { Motivasyon eksikliği ve } \\
\text { önemsememe } \\
\text { Yoğunluk } \\
\text { Fikrim yok }\end{array}$ & $\begin{array}{l}49 \\
35 \\
17 \\
12 \\
\\
6 \\
6\end{array}$ & $\begin{array}{r}39.2 \\
28.0 \\
13.6 \\
9.6 \\
4.8 \\
4.8\end{array}$ & $\begin{array}{l}x^{2}=6.54 \\
p=0.256\end{array}$ & $\begin{array}{l}x^{2}=5.51 \\
P=0.357\end{array}$ & $\begin{array}{l}\mathrm{X}^{2}=10.33 \\
\mathrm{P}=0.066\end{array}$ & $\begin{array}{l}x^{2}=8.70 \\
P=0.121\end{array}$ & $\begin{array}{l}x^{2}=4.78 \\
P=0.443\end{array}$ \\
\hline $\begin{array}{l}\text { Konu ile ilgili } \\
\text { eğitim alma } \\
\text { durumu }\end{array}$ & $\begin{array}{l}\text { Evet } \\
\text { Hayır }\end{array}$ & $\begin{array}{c}117 \\
8\end{array}$ & $\begin{array}{c}93.6 \\
6.4\end{array}$ & $\begin{array}{l}z=-1.62 \\
p=0.103\end{array}$ & $\begin{array}{l}\mathrm{z}=-2.02 \\
\mathbf{p}=\mathbf{0 . 0 4 3}\end{array}$ & $\begin{array}{l}\mathrm{z}=-2.15 \\
\mathbf{p}=\mathbf{0 . 0 3 1}\end{array}$ & $\begin{array}{l}\mathrm{z}=-0.83 \\
\mathrm{p}=0.407\end{array}$ & $\begin{array}{l}\mathrm{z}=-1.01 \\
\mathrm{p}=0.309\end{array}$ \\
\hline
\end{tabular}




\section{Tartışma}

Hemşirelerin tıbbi hatalara eğilimlerinin belirlenmesi amacı ile yapılan çalışmada grubun büyük çoğunluğu mesleki yaşam sürecinde herhangi bir tıbbi hatası olmadığını belirtmiştir. Elde edilen bu sonuç, yüksek bir oran olarak görülmekle birlikte, hastaların tıbbi hata nedeniyle zarar görmesini engellemek ve hemşirelerin yasalar karşısında kendilerini korumalarını sağlamak amacıyla bu oranın daha yüksek olması hedeflenmelidir ${ }^{18,19}$.

Çalışmamızda en fazla dikkatsiz çalışma stili, eğitim yetersizliği ve iletişimsizlik, işini umursamamak ve motivasyon eksikliğinin tıbbi hata nedenleri olabileceği belirtilmiştir. Alemdar ve Yaman ${ }^{17}$ yaptıkları çalışmada, hemşirelerin yorgunluk, iş yükünün fazla olması ve uzun çalışma saatlerinin, Gökdoğan ve Yorgun ${ }^{6}$ ise iletişimsizlik, sistemden kaynaklanan ve insan kaynaklı tıbbi hata nedenleri olabileceğini belirtmişlerdir. Benzer bir şekilde Bodur ve ark. $^{20}$ uzun çalışma saatlerinin, yorgunluk ve stresin ve hemşirelerin sayıca yetersiz olmasının tıbbi hatalara yol açabileceğini saptamışlardır. Çalışma sonuçlarımızın yapılan çalışmalar ile paralellik gösterdiği görülmektedir. Çalışan hemşire sayısının yetersiz olması nedeniyle oluşabilecek dikkatsiz çalışma, iletişim bozukluğu, motivasyon eksikliği, yorgunluk ve stres gibi etkenlerin tıbbi hata oranını arttırabileceği düşünülmektedir.

Çalışmamızda, Hemşirelikte Tıbbi Hataya Eğilim Ölçeğinden hemşirelerin alt boyutlara ilişkin aldıkları en yüksek puan ortalamasının, enfeksiyonun önlenmesi ve iletişim, en düşük puan ortalamasının ise hasta izlemi ve malzeme cihaz güvenliği olduğu belirlendi. Ölçeğin alt boyut puan ortalamaları incelendiğinde puan ortalamalarının yüksek olması nedeniyle, hemşirelerin tıbbi hata eğilimlerinin düşük olduğu söylenebilir. $\mathrm{Bu}$ sonucun yapılan benzer çalışmalar ile uyumlu olduğu görülmektedir. ${ }^{7,9}$ HTHEÖ alt boyutları incelendiğinde; "hasta izlemi ve malzeme cihaz güvenliğgi" alt boyutu ölçek puan ortalamasının diğer alt boyut puan ortalamalarına göre daha düşük olması, çalışma grubunu oluşturan hemşirelerde, bu alana yönelik tıbbi hata riskinin daha fazla olabileceğini düşündürmektedir. Çalışmanın özel kurumda yapılmasına karşın, malzeme-cihaz temini ve kullanımı ile ilgili sıkıntıların özel kurumlarda da yaşanabildiği görülmüştür. Oysa ki yanlış ya da uygun olmayan malzemelerin kullanılması hasta sonuçlarını doğrudan etkileyerek tedavi ve bakımın yanlış yönlendirilmesine ve hastanın zarar görmesine neden olabilir. Ayrıca hemşirelerin uygun olmayan malzemeleri kullanmaları, kendilerini yasal sorunlarla karşı karşıya bırakabilir. Dolayısıyla ilgili sağlık bakımı ile ilgili tüm tıbbi cihazların düzenli bakımı, kullanılan tüm sarf malzemelerinin kontrol edilmesi, sterilizasyon sürecine dikkat edilmesi gibi önlemler malzeme kullanımına bağlı hataların önlenmesinde önemlidir ${ }^{9}$. Bu 
bağlamda hemşirelere uygun malzeme temini ve kullanımına yönelik eğitimlerin yapılması gerekliliği düşünülmektedir.

Çalışmamızda hemşirelerin çalıştıkları klinikler ile "ilaç ve transfüzyon uygulamaları" alt boyutu puan ortalamaları, hemşirelerin daha önce hasta güvenliği hakkında eğitim alma durumu ile "enfeksiyonların önlenmesi" ve "hasta izlemi ve malzeme cihaz güvenliği” alt boyut puan ortalamaları arasında istatistiksel olarak anlamlı bir fark bulundu. Enfeksiyon kontrolü ve önlenmesi, sağlık kurumlarının önem verdiği konulardan biri olmasına karşın, sağlık uygulamalarının en zor alanlarından birisini oluşturmaktadır. Tedavi ve bakım hizmetlerinin uygulanmasında ortaya çıkabilecek enfeksiyonların azaltılması için, enfeksiyon kontrol talimatlarının geliştirilerek uygulanması, çalışanların eğitimi, enfekte atıkların uygun şekilde imha edilmesini gereklidir. ${ }^{21} \mathrm{Bu}$ doğrultuda, "enfeksiyonların önlenmesi” alt boyut puan ortalamasının diğer çalışmalara göre daha yüksek çıkması çalışma grubunun bu konuda bilinçli olduğunu göstermesi olumlu bir sonuç olarak değerlendirilmektedir.

Çalışma grubunu oluşturan hemşirelerin çoğunluğu hasta güvenliğine yönelik eğitim aldığını belirtmiştir. Gökdoğan ve Yorgun $^{6}$ hastanelerde güvenlik komitesinin, politikaların ve düşmeleri önlemeye yönelik programların olduğunu; hasta güvenliği konusunda hastanedeki ekip tarafından iyi eğitim verildiğini, hemşirelerin hasta güvenliğini sağlamak için eğitim düzeylerinin yeterli olduğunu, hasta güvenliğine ilişkin konuların belirlendiğini, Karaca ve $\operatorname{Arslan}^{22}$, hemşirelerin dörtte üçünün hasta güvenliği konusunda eğitim aldıklarını, eğitim alanların çoğunluğunun aldıkları eğitimi yeterli bulduklarını belirlemişlerdir. Çalışmamızda, hasta güvenliğine yönelik eğitim almanın diğer çalışmalara göre yüksek çıkmasının nedeni, araştırma grubunu oluşturan hemşirelerin özel kurumda çalışması ve bu kurumun hasta güvenliği konusunda hassas davranması olabilir. Diğer yandan sağlık hizmetlerinin sunumunda istenmeyen olay ya da tıbbi hataların önlenmesinde erken girişimlerde bulunabilmek için hemşirelerin bilgi ve becerilerinin güçlendirilmesi gereklidir. Çünkü hemşireler, çalıştıkları sağlık kurumlarında ve yönetim alanında sürekliliği olan etkin sağlık profesyonelleridir. Ayrıca, hemşireler sağlık hizmetlerinin sunumunda, bakımın planlanması, uygulanması ve değerlendirilmesinde, kalite güvenliğgine ilişkin çalışmalarda da etkin rol almaktadırlar. $\mathrm{Bu}$ bağlamda, hemşire mesleki bilimsel bilgi ve becerilerini uygularken, etik kurallar çerçevesinde, hasta haklarını koruyarak bu rol ve sorumluluklarını yerine getirmektedir. Ancak, yasaları ve zorunlulukları bilmeden yapılan girişimler hemşireleri yasalar önünde suçlu konuma düşürebilmektedir. ${ }^{16,23}$ Sağlık kurumunda uygulanan hasta güvenliğine ilişkin politikalar ve uygulamalar yetersiz olduğunda tıbbi hatalar ve hasta güvenliği açısından sorunlar sık görülebilmektedir. ${ }^{24}$ 


\section{Araştırmanın sınırlılıkları}

Çalışmanın tek bir kurumda yapılmış olması ve araştırmaya katılan hemşirelerin bildirimine dayanması araştırmanın sınırlılıklarını oluşturmaktadır. Ayrıca, çalışmanın özel kurumda yapılmış olması nedeniyle sonuçlar tüm kurumlara genellenemez.

\section{Sonuçlar ve Öneriler}

Araştırma kapsamına alınan hemşirelerin tıbbi hata yapma eğilimlerinin düşük olduğu, tıbbi hataların insan ve sistem kaynaklı oluşabileceği sonucuna ulaşıldı. Elde edilen sonuçlar doğrultusunda; sağlık kurumlarında, tıbbi hataları engellemek için hemşire ve diğer sağlık profesyonellerinde "Hasta Güvenliği”" bilincinin oluşturulması konusunda farkındalık geliştirilmesi, "Hasta ve Çalışan Güvenliği” komite/kurularının oluşturulması, özellikle hemşirelere, hasta güvenliği konusunda hizmetiçi eğitimlerin uygulanması ve bu eğitimlerin sürekliğinin sağlanması önerilmektedir.

\section{Kaynaklar}

1. Işık $\mathrm{O}$, Akbolat $\mathrm{M}$, Çetin $\mathrm{M}$, Çimen $\mathrm{M}$. Hemşirelerin bakışıyla tıbbi hataların değerlendirilmesi. TAF Preventive Medicine Bulletin 2012;11(4):421-430.

2. Kohn LT, Corrigan JM. To err is human: building a safer health system. Washington, DC: National Academy Press. 2000, 9-11.

3. Beyea S. Wake-up-call-standardization Iscrucial to Eliminating Medication Errors. AORN J 2002:75(5); 1010-3.

4. Preston RM. Drug Errors and Patient Safety: The Need for a Change in Practice. British Journal of Nursing 2004;13(2):72-8.

5. Çırpı F, Doğan Merih Y, Yaşar Kocabay M. Hasta güvenliğine yönelik hemşirelik uygulamalarının ve hemşirelerin bu konudaki görüşlerinin belirlenmesi. Maltepe Üniversitesi Hemşirelik Bilim ve Sanatı Dergisi 2009;2(3):26-34.

6. Gökdoğan F, Yorgun S. Sağlık hizmetlerinde hasta güvenliği ve hemşireler. Anadolu Hemşirelik ve Sağlık Bilimleri Dergisi 2010;13(2):53-59.

7. Özata M, Altunkan H. Hastanelerde tıbbi hata görülme sıklıkları, tıbbi hata türleri ve tıbbi hata nedenlerinin belirlenmesi: Konya Örneği. Tıp Araştırmaları Dergisi 2010;8(2):10011.

8. Türkmen E, Baykal Ü, Seren Ş, Altuntaş S. Hasta Güvenliği Kültürü Ölçeği'nin Geliştirilmesi. Anadolu Hemşirelik ve Sağlık Bilimleri Dergisi 2011; 14(4):38-46. 
9. Cebeci F, Gürsoy E, Tekingündüz S. Hemşirelerin tıbbi hata yapma eğilimlerinin belirlenmesi. Anadolu Hemşirelik ve Sağllk Bilimleri Dergisi 2012;15(3):188-196.

10. Weingart SN, Wilson RM, Harrison B. Epidemiology of Medical Error. British Medical Journal 2000; 320 (7237): 774-777.

11. Menachemi N, Shewchuk RM, O’Connor SJ, Berner ES, Allison JJ. Perceptions of Medical Errors by Internal Medicine Residents: Development and Validation of a New Scale. Quality Management in Health Care 2005; 14 (3): 144-154.

12. Polat $\mathrm{O}$, Pakiş I. Tıbbi uygulama hatalarında hekim sorumluluğu. Acıbadem Üniversitesi Sağllk Bilimleri Dergisi 2011;2(3):119-125.

13. Esatoğlu E, Akbulut Y. Hasta güvenliğinde iş tasarımının önemi ve bir model önerisi. I. Uluslararası Hasta Güvenliği Kongre Kitabı, Antalya. 2007. 27-32.

14. Dhillon BS. Human reliability and error in medical system. Series on industrial \& system engineering 2003; 2: 10-18.

15. Farquhar M, Sharp BAC, Clancy CM. Patient safety in nursing practice. AORN J 2007; $86: 455-7$.

16. Aştı T, Acaroğlu R. Hemşirelikte Sık Karşılaşılan Hatalı Uygulamalar. Cumhuriyet Üniversitesi Hemşirelik Yüksekokulu Dergisi 2000;4 (2): 22-27.

17. Alemdar Küçük D, Yaman Aktaş Y. Türkiye'de Hemşirelik Hizmetlerinde Tıbbi Hata Türleri ve Nedenleri. TAF Prev Med Bull 2013; 12(3):307-314

18. Brady AM, Malone AM, Fleming S. A literature review of the individual and systems factors that contribute to medication errors in nursing practice. Journal of Nursing Management 2009;17(6):679-97.

19. Anderson B, Stumpf PG, Schulkin J. Medical error reporting, Patient Safety, and the Physician. Journal of Patient Safety 2009;5(3):176-9.

20. Bodur S, Filiz E, Durduran Y. Sağlik personeli ve toplumun tıbbi hatalar ile ilgili görüşlerinin karşılaştırılması. Genel Tıp Derg 2011;21(4): 123-130.

21. Anezz E. Clinical perspectives on patient safety. In:K Wals, R Boaden (Eds.), Patient Safety Research in to Practice. (1st ed.) London: McGraw Hill Education Open University Press; 2006. p.9-18.

22. Karaca A, Arslan H. Hemşirelik hizmetlerinde hasta güvenliği kültürünün değerlendirilmesine yönelik bir çalışma. Sağlık ve Hemşirelik Yönetimi Dergisi 2014;1(1):9-18. 
23. International Council of Nurses (ICN). Why is safe staffing importent? Safe Staffing Saves Lives. International Nurses Day, Information and Action Tool Kit. 1st ed. Geneva: ICN International Council of Nurses; 2006.p.9-12.

24. Olden PC, MCCaughrın WC. Designing Healthcare Organizations to Reduce Medical Errors and Enhance Patient Safety. Hospital Topics: Research and Perspectives on Healthcare 2007; 85(4):4-9. 